\title{
陸棚に形成された海底谷を埋積したスランプ堆積物 一東北日本南部福島県太平洋沿岸に分布する鮮新統大年寺層の例一
}

\author{
小佐野 由布子 $*$. 保柳 康一 $* *$. 近藤 はるか $*$ ・柳沢 幸夫 $* * *$
Submarine canyon-fill slump deposits on the shelf environment of the Pliocene Dainenji Formation on the Pacific coast in Fukushima, northeastern Japan

\author{
Yuko Osano*, Koichi Hoyanagi**, Haruka Kondo* and Yukio Yanagisawa***
}

\begin{abstract}
The Dainenji Formation is deposited on shelf environment and consists mainly of sandy siltstone and sandstone. It includes a number of volcanic ash layers, which serve as good key beds useful for precise correlation. Mappable units of submarine canyon-fill sediment are recognized in this area. A valley has a maximum depth of $100 \mathrm{~m}$ and is considered to be formed by submarine landslide, which took place after $2.7 \mathrm{Ma}$. Submarine canyon-fill sediments are composed of siltstone interbedded with thin sandstone layers, thick sandstone beds and slump deposits. Formation and filling of the submarine canyon might be controlled by climate cooling of latest Pliocene.
\end{abstract}

Key words : Dainenji Formation, submarine canyon, slump deposits, Pliocene

\section{はじめに}

茨城県から福島県を経て宮城県の太平洋沿岸地域（第 1 図）に分布する仙台層群大年寺層は鮮新世の陸棚堆積物 で, 主要に砂質シルト岩などの細粒堆積物からなり, 下部 の砂岩相（D1）上上部の泥岩相（D2）, 砂岩泥岩相（D3）, 泥岩砂岩相（D4）の 4 つの岩相に区分されている（久保ほ か，1990，1994，2000）。これら区分された岩相は，2004年 改定の「日本地質学会地層命名の指針」に従う之, 大年寺 層の部層区分に相当する。したがって，この論文では，以 下 4 つの岩相を $\mathrm{D} 1$ 部層, $\mathrm{D} 2$ 部層, $\mathrm{D} 3$ 部層, $\mathrm{D} 4$ 部層と簡

受付: 2006 年 12 月 12 日 受理 : 2007 年 1 月 24 日

* 信州大学大学院工学系研究科

Graduate School of Science and Technology, Shinshu University, 3-1-1 Asahi, Matsumoto 390-8621, Japan

** 信州大学理学部地質科学科

Department of Geology, Faculty of Science, Shinshu University, 3-1-1 Asahi, Matsumoto 390-8621, Japan

*** 産業総合研究所地質情報研究部門 Geological Survey of Japan, AIST, Chuo-7, 1-1-1 Higashi, Tukuba, 305-8567, Japan
略化して呼称する.

これら 4 部層のうち, 南の富岡町から浪江町をへて北の 小高町にいたる海岸沿いに分布する大年寺層の最上部の部 層である D4 部層は, D2 部層を削り込んだ巨大な海底谷を 埋積して堆積していることが知られている（久保ほか, 1994).

この研究では, 大年寺層 $\mathrm{D} 4$ 部層中の堆積構造の詳細な 記載から，海底谷の成因について考察した。

\section{D2 部層と海底谷を埋積した D4 部層との関係}

海底谷を埋積している D4 部層の基底は, 北の小高町付 近では D2 部層下部に挟在する火山灰鍵層 SF21 の上位に 存在するすべり面である，南へ向かってそのすべり面は層 準を下げ，浪江町や富岡町では D2 部層と D1 部層を区切 る火山灰鍵層 SF11 の直上に位置する (第 2 図)。 D4 部層 には D2 部層に見られない火山灰が挟在し, D2 部層が珪藻 化石帯 (Yanagisawa and Akiba, 1998) の NPD8 帯に対比で きるのに対し D4 部層の主要部分が NPD9 帯に対比できる （柳沢, 1990）。これらのことから, ここでの D2 部層の欠如 


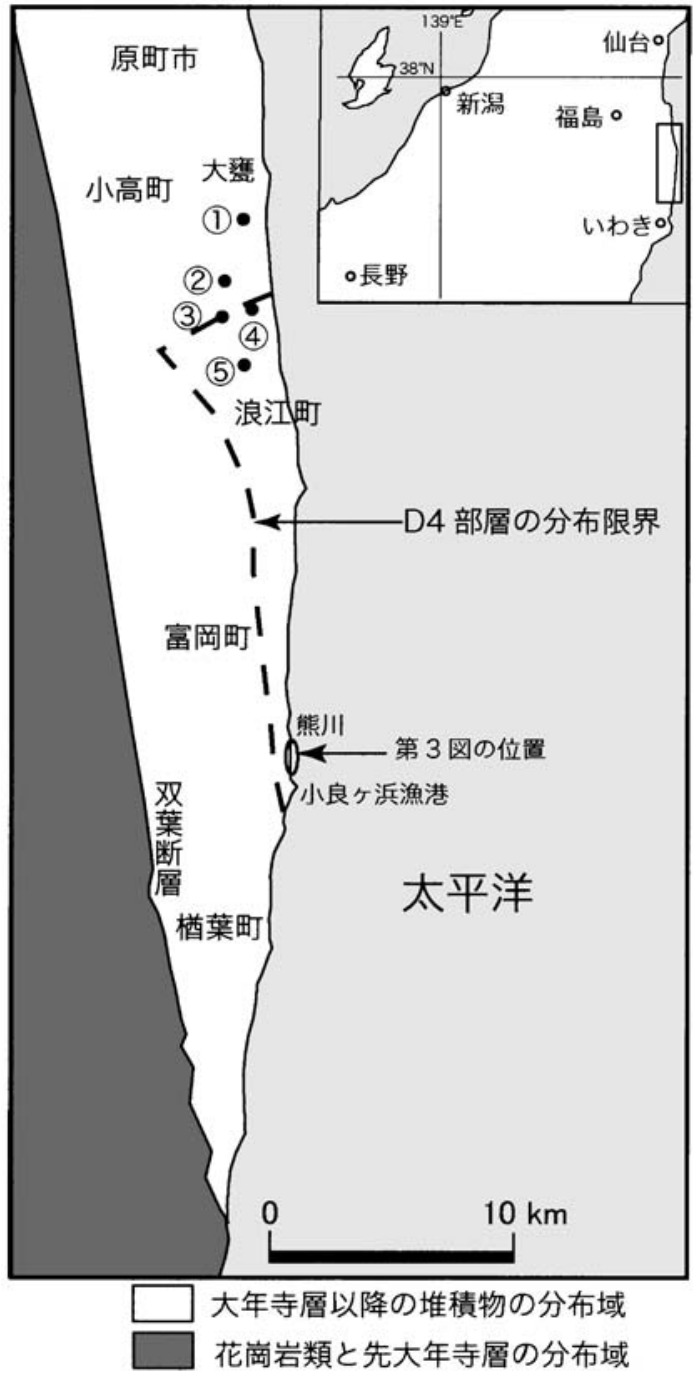

第 1 図調査地域位置図. (1)〜(5) は第 2 図の柱状作成地点.

量は層厚にして $100 \mathrm{~m}$ 以上と見積もられている（久保ほ か, 1990).

海底谷基底のすべり面直上には，D2 部層に起源をすつ ブロックが存在することがある（第 2 図 (3) (4)）。また，D2 部層の最下部付近の細粒部分がすべり面となっていること が多い，一方，南部では基底に下位の地層のブロックが残 されず，D4 部層基底の砂岩層がすべり面を覆っている（第 2 図 (5)). D4 部層の北端は, 北北東-南南西の壁をつくって いる。一方, 地表分布の南限では, D2 部層むしくは D1 部 層の上位に D4 部層が緩い傾斜で重なっている.

このように D4 部層は海底地すべりを起源とする海底谷 埋積堆積物として認識されているが，海底地すべりは断続
的に複数回起こっており，D4 部層は D4a，D4b，D4c に細 分されている（柳沢ほか，2003）。

\section{D4 部層中のスランプ堆積物}

D4 部層全体が海底谷を埋積したものであるが，D4 部層 内には，スランプ構造を示す堆積物が見られる．D4 部層分 布域の南部にあたる熊川と小良ヶ浜漁港間の海蝕崖で, D4 部層中のスランプ堆積物の構造を詳細に観察した（第 3 図)。この露頭は, 柳沢ほか (2003) の Fig. 4 で小良ヶ浜北 とされた露頭で，D4b，D4c，D4a が分布している。第 3 図 は, 北から $\mathrm{A}, \mathrm{B}, \mathrm{C}, \mathrm{D}$ の順に連続した東向きの露頭を示し ている。

第 3 図 A : 砂質シルト岩に対して, 北側から南に向かっ てダウンラップする偽碟を含む細粒砂岩層が見られる。

第 3 図 B : 上部の偽碟を含む細粒砂岩層が連続し, やは り南に向かうダウンラップ構造を示す，砂岩層中には層内 の正断層，またその南側には層内の逆断層などの破壊構造 が見られる。 下部は，砂質シルト岩優勢の砂岩シルト岩互 層からなる。

第 3 図 C : これまで南側からダウンラップしてきた砂岩 層が砂質シルト岩層の下に潜り込む構造を取っている，砂 岩層が北から南向かって打ち込まれたようなくさび形の構 造をとる. そのくさびの先端では, 泥岩が数 $\mathrm{cm}$ から $10 \mathrm{~cm}$ ほどの偽礧状になっており，砂層の流動化によって泥層の 取り込みが扔こなわれている様子が見られる。

第 3 図 D : 下位を削り込むチャネル構造を基底に持つ偽 䃇を含む粗粒加ら細粒砂岩からなる砂岩層之变形した薄層 細粒砂岩層を挟在するシルト岩層, そしてそれらを覆う細 粒砂岩層を挟在するシルト岩層からなる，現在，砂岩層は 崖崩れ堆積物によってほとんど覆われてしまっているが， 南に向かってくさび形に見える偽磁を含む砂岩層は，現在 崩壊堆積物によって覆われている北側で下位のシルト岩を 侵食して厚く堆積していたことが観察されている。 また, 変形を受けているシルト岩は，一部に細粒砂が流動して入 り込んで抢り，またこの変形によってっくられた凹地を埋 めるように，上位のシルト岩層は南に向かってオンラップ して堆積している.

\section{海底谷の形成とその埋積}

\section{1. 様 式}

D4 部層はその分布の北限で，北側と西側で高角の壁を 持って D2 部層と接する。このことから，海底谷は北西部 を谷頭として北側に壁を屯ち，谷は南東に向かって延長し ていたと考えられる。一方, D4 部層分布域南部で見られる 


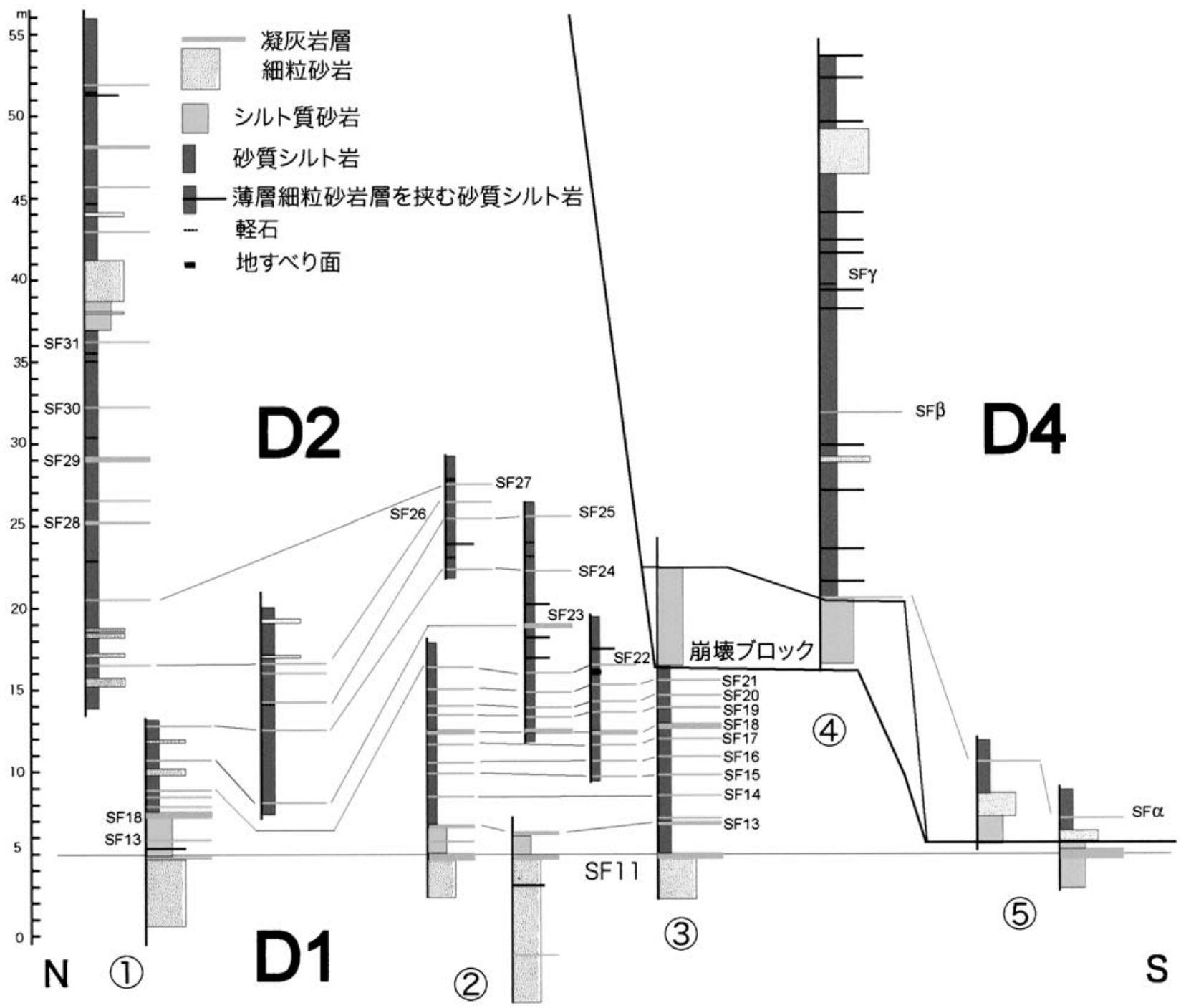

第 2 図大年寺層中部・上部の柱状図.

SF : 柳沢ほか（2003）に基づき対比可能な火山死層.

海底谷内を埋めている堆積物の特徵（第 3 図）は，この時 期粗粒な堆積物がチャネルを形成して急激に海底谷に流れ 込んだことを示している．近藤ほか（2007）は大年寺層が 陸棚上で前進後退を繰り返したデルタシステムの堆積物で あるとしており, 第 3 図 D に見られる細粒砂岩層を挟在す るシルト岩層はプロデル夕環境を示すと考えられる。この 地域北西にあったとされるデルタシステム（近藤ほか, 2007）の急速な前進が，削り込みによる偽碟を含む粗粒砂 をこの地域にもたらしたと考えられる。その急速で大量の 堆積による荷重によって, 第 3 図 D に見られる変形をシル 卜主体の下位の陸棚堆積物に与えた。第 3 図 A, B に見ら れる北から南に向かって, ダウンラップ構造を示して前進
している砂岩層は，デルタフロント堆積物だと考えられ る。その後, デル夕の後退により，再び薄層の砂岩層を挟 在するシルト岩層からなるプロデルタでの堆積が開始され る. 沖側ではチャネルの埋積残りの凹地を埋めて, 細粒の 混濁流から細粒砂とシルトが堆積し, 凹地の縁のオンラッ プ構造をつくった，不安定なデルタフロントは，海底地す ベりを引き起こし，移動したデルタフロントの砂層は，上 位のプロデルタのシルト岩中との境界で変形と液状化を起 こして, 第 3 図 $\mathrm{B}, \mathrm{C}$ にられる変形構造が形成された。

\section{2. 要 因}

巨大海底谷形成の引き金となった最初の海底地すべり （D4a）は珪藻化石帯の NPD 8 帯（Yanagisawa and Akiba, 

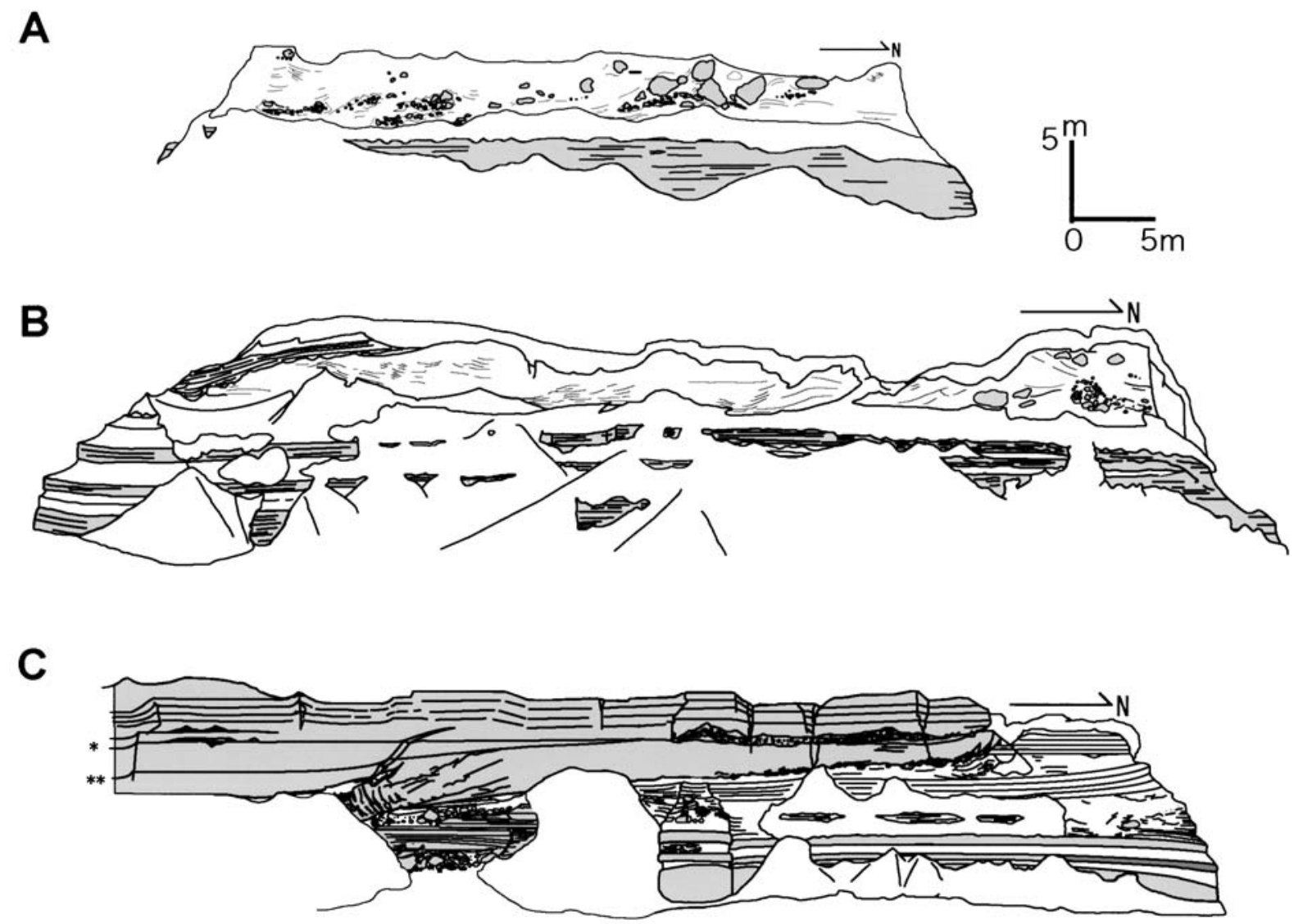

D

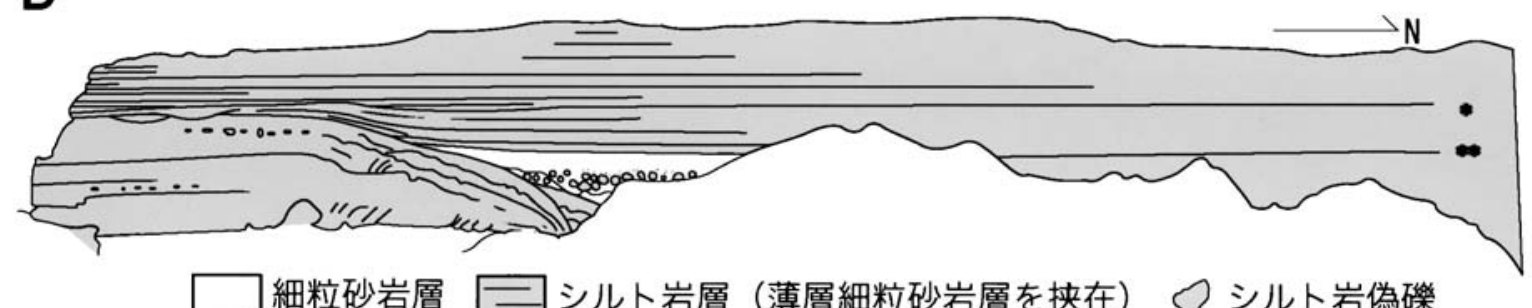
モ 砂岩層中のダウンラップ構造

第 3 図 熊川-小良ヶ浜漁港間の海蝕崖に見られる D4 部層の構造.

北から A, B , C, D の順に配列， C, D の*と**は，それぞれ連続する薄層砂岩層.

1998）最上部に属し，3.0-3.1 Ma の生層準と 2.6-2.7 Ma の 生層準の間にあり, さらに層厚と堆積速度を考慮すると, 2.6-2.7 Maの生層準に極めて近い年代と推定される（柳沢 ほか，2003）。そして，この年代は鮮新世末の寒冷化開始時 期と一致している。背弧堆積盆地の新潟県西頸城地域の鮮 新統の名立層中の海底チャネル形成は, $2.7 \mathrm{Ma}$ 頃の海水準
低下に伴うシーケンス境界とされる（大村，2000）。年寺 層の海底谷形成むほぼ同じ時代であり，2.7 Ma 頃に開始さ れる汎世界的海水準低下 (Shackleton et al., 1995) に対応す るかもしれない，海底谷基底のブロックとそれを覆う砂岩 層は，薄層細粒砂岩層を挟在するシルト岩層に覆われる. これは, $2.5 \mathrm{Ma}$ 頃の温暖期に対応され, チャネルの形成と 
デルタフロントの前進によるスランプ層の形成は，その後 $2.3 \mathrm{Ma}$ 頃から $2.1 \mathrm{Ma}$ にかけての寒冷化に対比させること が出来るかもしれない.

このように鮮新世末に始まった寒冷化が陸棚環境の堆積 作用に強く影響していた可能性がある.

\section{謝 辞}

研究費用の一部に科学研究費基盤研究 (C), 課題番号 18540451 （研究代表者: 保柳康一）を用いた。

\section{文献}

近藤はるか - 小佐野由布子 - 吉田真見子 - 保柳康一 ・ 柳沢幸夫, 2007 : 福島県上部鮮新統大年寺層に打ける陸棚の堆積作用 と気候变動の関係, 堆積学研究, no. 64, 77-81.

久保和也 - 柳沢幸夫 ・ 利光誠一 - 板野靖行 - 兼子尚知 $\cdot$ 吉岡敏

和・高木哲一，2000 : 地域地質研究報告， 5 万分の 1 地質図

幅「川前及び井出地域の地質」, 地質調査所, $136 \mathrm{p}$.

久保和也・柳沢幸夫・吉岡敏和・高橋 浩, 1994 : 地域地質研究
報告， 5 万分の 1 地質図幅「浪江及び磐城富岡地域の地質」, 地質調查所, $104 \mathrm{p}$.

久保和也・柳沢幸夫・吉岡敏和・山本孝広・滝沢文教, 1990 : 地 域地質研究報告, 5 万分の 1 地質図幅「原町及び大甕地域の 地質」, 地質調查所, $155 \mathrm{p}$.

大村亜希子, 2000 : 新潟県西頸城地域に分布する鮮新統の第 3 オーダー堆積シーケンスと有機物組成, 地質学雑誌, 106, 534-547.

Shackleton, N.J., Hall, M.A. and Pate, D., 1995 : Pliocene stable isotope stratigraphy of site 846. Proc. ODP Sci. Res., 138, 337355.

柳沢幸夫, 1990 : 仙台層群の地質時代一珪藻化石層序による再検 討一. 地調月報, 41, 1-25.

Yanagisawa, Y. and Akiba, F., 1998 : Refined Neogene diatom biostratigraphy for the northwest Pacific around Japan, with an introduction of code number for selected diatom biohorizons. Jour Geol. Soc. Japan, 104, 395-414.

柳沢幸夫 ・高橋友啓・長橋良隆・吉田武義・黑川勝己, 2003 : 福 島県太平洋岸に分布する鮮新統大年寺層のテフラ層一その 1. 年代層序一. 地質調查研究報告, 54, 351-364. 